\title{
Sastra Suluk Jawa Pesisiran: Membaca Lokalitas dalam Keindonesiaan
}

\author{
Toha Machsum*)
}

\begin{abstract}
Abstrak
Sastra Suluk sebagai salah satu jenis karya sastra Jawa pesisiran mengandung ajaran kerohanian tasawuf atau bernuansa tasawuf yang berupa petunjuk tentang keyakinan, sikap, tata cara yang dilakukan seseorang untuk mengenal hidup kesejatian di hadapan Sang Maha Pencipta atau untuk mencapai posisi sedekat-dekatnya dengan Tuhan. Secara umum studi sastra suluk diarahkan untuk mengangkat salah satu warna kebudayaan kerohanian bangsa. Pengangkatan nilai-nilai budaya lama lewat studi karya sastra suluk akan memberikan manfaat bagi masyarakat dalam rangka memepertahankan jati diri ketimuran. Dikatakan demikian, karena pada saat ini peradaban global yang sudah tidak lagi kenal batas-batas ruang waktu, tidak hanya menyajikan unsurunsur positif bagi pemikiran dan kemajuan umat, tetapi juga menawarkan filsafat materialisme dan skularisme yang sangat membahayakan bagi kehidupan ketimuran yang menjunjung nilai-nilai agama dan filsafat ketuhanan. Globalisasi dalam hal ini tidak menawarkan kebudayaan, tetapi menawarkan sebuah peradaban. Lebih lanjut, pemahaman dan pengenalan terhadap nilai-nilai budaya masa lampau yang terdapat dalam naskah suluk bukan saja merupakan modal utama bagi pembangunan nasional yang diamanatkan oleh GBHN, melainkan juga memberikan informasi mengenai berbagai aspek kehidupan masyarakat masa lampau, seperti sosial, politik, ekonomi, dan budaya.

Corak keberagaman Islam tersebut lebih jauh akan memberikan inspirasi dan sekaligus menggerakkan kehidupan kebangsaan Indonesia. Dengan kata lain corak keberagamaan Islam tersebut mewarnai konsep berpikir masyarakat Indonesia.
\end{abstract}

Kata kunci: Sastra Suluk, Pesisiran, Lokalitas, dan Keindonesiaan

\section{Pengantar}

Untuk melihat secara jelas fenomena Islam dalam Indonesia kontemporer dengan berbagai problemnya, orang tidak boleh melompat ke abad ke-19 atau 20 secara langsung. Secara kultural, ia perlu melihat jauh ke belakang, yakni abad ke-15, 16, dan 17. Ada kesinambungan warisan budaya dan cara berpikir antargenerasi yang sulit diputuskan

\footnotetext{
*) Magister Agama, Pembantu Pimpinan pada Balai Bahasa Provinsi Jawa Timur
} 
begitu saja. Budaya adalah cara berpikir, pandangan hidup, falsafah, pandangan dunia, dan pandangan keagamaan pada umumnya, yang membentuk perilaku manusia dalam hidup kesehariannya (Abdullah, 2000:189).

Fenomena keislaman abad ke-15 dan 16 di tanah Jawa masih tampak dapat dibaca dalam lipatan literatur-literatur keagamaan Islam. Tentunya, pembahasan dalam literatur-literatur tersebut menggambarkan dialektika sebuah wacana dan konteks keagamaan masa lalu serta tidak jarang muncul kembali dalam bentuk yang lain dalam masa sekarang sehingga fungsi naskah menjadi sangat penting untuk menjembatani masa lalu dan sekarang.

Sebagai rekam jejak kehidupan sosial-intelektual keagamaan masa lalu literatur-literatur itu tersimpan dalam jumlah yang sangat besar. Salah satu naskah Nusantara dalam jumlah yang besar itu adalah naskah keagamaan yang berbentuk sastra suluk. Berdasarkan pengamatan, diketahui bahwa pada saat ini di Indonesia terdapat lebih dari 104 judul karya sastra suluk. Sebagian besar karya sastra itu masih belum terjamah dan masih memerlukan penelitian lebih lanjut.

Sastra Suluk merupakan salah satu jenis sastra Jawa pesisir dan sekaligus merupakan hasil budaya masyarakat pesisir. Dengan demikian dalam konteks kebudayaan, sastra suluk merupakan ekspresi sastra yang berasal dari masyarakat atau kelompok, khususnya Jawa, yang berdiam di daerah pesisir, khususnya bagian utara pulau Jawa, dan mempunyai fungsi tertentu bagi masyarakat pendukungnya. Dalam hal ini, sastra suluk dapat dianggap sebagai buku pedoman bagi anggota masyarakat, baik secara perorangan maupun keseluruhan. Selain itu, sastra suluk juga memungkinkan memberikan inspirasi pembentukan sebuah norma, baik 
bagi orang-orang yang hidup pada waktu tertentu maupun bagi orangorang yang hidup di kemudian hari.

Sastra suluk sebagai salah satu bentuk sinkretisme agama dan budaya dapat dijadikan bahan pertimbangan utama dalam pengembangan pluralisme. Dalam peristiwa sejarah misalnya, spiritualitas keislaman Jawa tersebut mampu menunjukkan sikap toleransi menerima konsep Ketuhanan Yang Mahaesa dan mampu menunjukkan sikap akomodatif terhadap berbagai budaya baru yang datang. Oleh karena itu, warisan budaya tersebut perlu diapresiasikan dengan baik, karena keberhasilannya yang luar biasa dalam memelihara kemajemukan.

Tulisan ini akan melihat ulang prestasi budaya dan sejarah perkembangan Islam di tanah Jawa berdasarkan data-data yang ditemukan pembahas dalam naskah sastra suluk Jawa pesisir. Kajian ini juga hendak membaca mengenai lokalitas dalam keindonesian sastra suluk Jawa pesisiran.

\section{Pembahasan}

\subsection{Sastra Suluk Pesisiran: Hasil Pergulatan antara Islam dan Sastra Jawa}

Para ahli sepakat bahwa abad ke-15, daerah pesisir utara Jawa seperti, Tuban Gresik, Demak, Cirebon, dan Banten telah menjadi basis utama penyebaran agama Islam di Jawa. Di tempat-tempat itu, para mubalig sebagai pelopor penyebaran Islam di Jawa harus merangkak dari lapisan bawah dan menyebar melalui masyarakat pedesaan sepanjang pesisir. Hal itu dilakukan lantaran penyebaran agama Islam di Jawa berhadapan dengan kekuatan tradisi besar budaya kerajaan Majapahit yang telah dihaluskan dengan unsur Hinduisme (Simuh, 1998:19). Selain itu, tradisi budaya dan sastra Hindu kejawen juga telah tertanam cukup 
kuat dan dikembangkan menjadi sendi-sendi kehidupan politik kebudayaan kerajaan-kerajaan kejawen semenjak zaman jauh sebelum Islam (Simuh, 1999:17). Simuh dalam Tohari (1998:19) menyebutkan lebih dari tiga abad Islam dipandang sebagai agama dan budaya asing di lingkungan tradisi budaya kerajaan Majapahit.

Di sepanjang lapisan masyarakat bawah di pedesaan (baca: pesisiran) mereka mendapatkan sambutan yang hangat bahkan dipandang sebagai rahmat untuk keluar dari kegelapan. Di daerah-daerah itu, mereka bersama masyarakat mendirikan basis-basis penting berupa pusat-pusat religi yang cukup kuat dan strategis. Basis-basis yang menjadi pusat semacam ini sekarang dikenal dengan nama pondok pesantren (Pegeaud dalam Purnomo, 2002:10). Disebutkan bahwa pondok pesantren pada waktu itu telah menjadi basis utama aktualisasi nilai-nilai Islami di dalam masyarakat Jawa. Di sini mereka secara perlahan-lahan berusaha mengubah sosio kultural Jawa Hindu menjadi sosio kultur Jawa yang bersifat Islami (Hamka, 1976:145-146). Proses penyebaran Islam di daerah pesisir yang diikuti mengalirnya kepustakaan agama melahirkan lingkungan tradisi baru yang dinamakan budaya pesantren, yang mau tidak mau merupakan tradisi agung kedua yang mengimbangi tradisi agung di lingkungan istana (Simuh, 1999:18).

Selain hal di atas, di pondok pesantren juga terjadi kegiatan olah sastra yang cukup produktif. Kegiatan olah sastra yang dijiwai dengan semangat keagamaan menjadikan pondok-pondok pesantren menjadi pusat kesusastraan pada waktu itu. Pegeaud dalam Hadi (2003:447) menyatakan bahwa pada abad 15-16 (zaman pesisir) kegiatan sastra berpindah ke kota-kota pesisir yang merupakan pusat perdagangan dan penyebaran Islam. Berbagai sastra yang bercorak tasawuf atau sufistik banyak digubah di sana seperti, primbon, wirid, dan suluk. Berkenaan 
dengan hal itu, benar kalau Simuh dalam Tohari (1998:21) menyatakan bahwa abad 16 mempunyai arti yang penting bagi sejarah penyebaran Islam di Indonesia dan munculnya sastra Jawa Islam.

Selanjutnya, Simuh menyatakan bahwa pada abad ke-16 muncul kerajaan-kerajaan pesisiran, seperti kesultanan Banten, Cirebon, dan Surabaya, serta kesultanan Demak. Disebutkan kesultanan Demak adalah yang terbesar. Meningkatnya kebesaran kerajaan Jawa-Islam-Demak yang diikuti surutnya kerajaan Jawa Hindu Majapahit menyadarkan pada cendikiawan dan sastrawan Jawa untuk menyadap ilmu dari sastra budaya pesantrenan.

Berdasarkan konsep pemikiran di atas, hasil interaksi Islam dengan sastra budaya Jawa melahirkan dua bentuk sastra Jawa, yaitu sastra suluk pesantrenan dan sastra Islam Kejawen. Sastra suluk pesantrenan, baik yang berbahasa Jawa maupun yang berbahasa Arab, umumnya cenderung memuat paham transendensi Tuhan, yakni Tuhan diyakini sangat berbeda dan di atas segala makhluk. Pegeaud dalam Damami dan Purnomo (2001:300) menyebutkan, jenis sastra seperti ini, berdasarkan kesejarahannya kemudian disebut dengan sastra suluk pesisiran (pesisir literature) Sementara sastra suluk Islam kejawen kebanyakan berbahasa Jawa dan isinya cenderung ke arah panteisme atau monisme. Sastra suluk jenis ini berdasarkan kesejarahannya disebut sastra suluk kraton.

Pigeaud dalam Hadi, (2003:449) menyatakan kota-kota pesisir yang memainkan peran penting dalam penulisan kitab agama dan karya sastra adalah Gresik, Tuban, Sedayu, Surabaya, Demak, dan Jepara. Selanjutnya kegiatan sastra pesisir menyebar ke Cirebon dan Banten di Jawa Barat, Sumenep dan Bangkalan di Pulau Madura, kemudian Pasuruan, Besuki, Situbondo, dan Banyuwangi. Sastra Jawa pesisir tidak 
hanya berpengaruh di daerah pesisir pulau Jawa, tetapi juga ke tempat lain, seperti Palembang, Lampung, Banjarmasin, dan Lombok. Bahkan, kegiatan itu kemudian dikembangkan di pedalaman Jawa, khususnya di Kraton Surakarta dan Yogyakarta serta daerah-daerah lain di sekitarnya, seperti Banyumas, Kediri, dan Madiun

\subsection{Sastra Suluk Pesisiran: Warna Lokal Spiritualitas Islam Jawa}

Dalam Khazanah sastra Jawa banyak tersimpan karya sastra Islam atau karya sastra yang bernafaskan Islam (Baried, 1995:5-7). Sastra Islam dan sastra Jawa yang mendapat tempat tersendiri serta yang sangat menarik diamati adalah jenis sastra suluk. Sastra suluk sebagai salah satu jenis karya sastra Jawa pesisiran mengandung ajaran-ajaran kerohanian tasawuf atau bernuansa tasawuf yang berupa petunjuk tentang keyakinan, sikap, dan tata cara yang dilakukan seseorang untuk mengenal hidup kesejatian di hadapan Sang Maha Pencipta untuk mencapai posisi sedekat-dekatnya dengan Tuhan. Simuh (1996:74) menyatakan bahwa sastra suluk tersebut pada masa penyebaran agama Islam sangat digemari oleh masyarakat Jawa. Hal itu disebabkan oleh kekhasan sistem estetika yang dimilikinya, yaitu pemanfaatan simbol dan bentuk-bentuk alegoris untuk mendekati manifestasi ide-ide ketuhanan. Berkenaan dengan hal itu, para sejarawan juga mengakui bahwa pendekatan sufisme atau mistisime memegang peran kunci dalam penyebaran Islam masa awal di Indonesia. Bahkan sufisme merupakan daya tarik tersendiri yang memikat orang-orang Nusantara.

Istilah suluk berasal dari kata Arab salaka-yasluku-sulukan yang berarti melalui jalan (Munawwir, 1997:653). Dalam KBBI (2008:1352) kata suluk mempunyai arti jalan ke arah kesempurnaan batin. Dari segi terminologi istilah suluk berarti perjalanan kerohanian menuju kepada 
Tuhan, perjalanan di jalan spiritual menuju Sang Sumber di bawah bimbingan guru spiritual (pir, syaikh, mursyid) (Armstrong dalam Purnomo dan Damami, 2001:299).

Menurut al-Ghazali, hakikat perjalanan spiritual adalah tata cara, tahap-tahap yang harus ditempuh untuk dapat sampai sedekat-dekatnya dengan Sang Pencipta. Tahap-tahap tersebut mencakup pengosongan diri dari sifat-sifat buruk, yang berupa perbuatan maksiat, baik yang bersifat lahir maupun batin, kemudian dilakukan pengisian dengan sifat-sifat terpuji yang berupa ketaatan lahir dan batin. Keberhasilan perjuangan spiritual itu, menurutnya ditandai oleh terbukanya tabir atau hijab antara manusia dengan Sang Pencipta (baca: makrifat) (al-Taftazani, 1997:168-169).

Perkembangan spiritualitas Islam Nusantara sejak awal diwarnai oleh dua model tradisi. Pertama mistik bercorak union mystik (heterodoks), yaitu paham yang membolehkan pemahaman kesatuan manusia dengan Tuhan. Kedua, mistik ortodoks, yaitu paham mistik yang berpedoman pada normativitas syariah. Dengan kata lain bahwa perkembangan mistisme Islam di Jawa terkait dengan dua tradisi mistik ortodoks dan heterodoks. Namun, Purnomo dan Damami (2001:300) menyatakan bahwa perkembangan Islam yang terkait dengan tradisi mistik ortodoks lebih dominan daripada tradisi mistik heterodoks. Hal itu disebabkan literatur keagamaan Islam yang mengalir ke Jawa (dan Indonesia) adalah literatur dari Timur Tengah. Disebutkan bahwa literatur keagamaan dari Timur Tengah pada umumnya sangat memperhatikan amalan-amalan syariah. Oleh karena itu, tidak mengherankan kalau tasawuf yang ditawarkan pada waktu itu adalah tasawuf yang sangat kental corak syariatnya. Hal itu tentunya juga tidak dapat dilepaskan dari pesantren yang merupakan lembaga pendidikan 
agama khas Jawa yang mengajarkan ilmu-ilmu agama dari Timur Tengah. Selain itu, pesantren juga akomodatif dengan tradisi-tradisi yang cenderung moderat dan memberikan legitimasi bagi budaya lokal. Corak tasawuf seperti itulah yang kemudian memengaruhi ide-ide sastra suluk Jawa pesisiran.

Ajaran utama yang diajarkan mistik ortodoks adalah untuk mencapai derajat manusia sempurna (Insan Kamil) seseorang harus menempuh tahapan-tahapan seperti, syariah, tarikat, hakikat, dan makrifat. Menurut perspektif tradisi ini laku mistik harus diwadahi dalam syariat, dimulai dengan ibadah fisik dalam panduan agama hingga tingkat tertinggi yang dibolehkan syariat, yaitu makrifat. Literatur sufisme yang sering dijadikan rujukan yang paling utama adalah ajaran-ajaran alGhozali. Woodward dalam Murtadho (2002:52) menyebutkan sumber rujukan tradisi ortodoks adalah al-Ghozali bersama al-Junaid. Sementara Azra (1994:245) menyebutkan tiga tokoh, yaitu al-Ghozali, al-Junaid, dan al-Qusyairi

Warisan spiritualitas Islam yang bersifat sufistik tersebut dapat dibuktikan dalam literatur-literatur keagamaan Islam yang banyak terdapat dalam naskah-naskah sastra suluk Jawa pesisiran. Literaturliteratur itu banyak dipakai sebagai referensi dalam praktik Islam Jawa. Literatur-literatur yang dijadikan rujukan praktik Islam Jawa antara lain, Suluk Sujinah, Suluk Kangkung, Suluk Residriya, Serat Ngabdul Jalil dan lain-lain. Dalam naskah-naskah tersebut unsur kebatinan Jawa masih tampak jelas. Hal itu dapat dilihat misalnya pada Suluk Sujinah. Diceritakan bahwa perkawinan Dewi Sujinah berlangsung setelah ia melakukan keprihatinan yang panjang pada masa gadisnya, karena rindu pada ilmu hakikat. Kerangka itu merupakan aspek simbolis dari ajaran syariat, tarikat, dan makrifat. Masa gadis Dewi Sujinah adalah masa 
syariat, pertemuan dan dialog dengan Pendeta Mustakim adalah tataran tarikat dan hakikat. Sementara percintaan dalam perkawinannya adalah simbolisme bagi tingkatan makrifat. Hal itu juga dapat dilihat pada Serat Ngabdul Jalil, bahwa perjalanan Abdul Jalil dalam mencari ilmu sampai bertemu dengan Sunan Ampel dan bertapa di hutan Siti Jenar adalah simbolisme perjalanan dari syariat sampai dengan makrifat.

Unsur-unsur kebatinan Jawa seperti di atas juga tampak pada Suluk Residriyo dan Suluk Kangkung. Dalam kitab-kitab itu disebutkan bahwa untuk mencapai realitas yang paling mendasar, manusia harus menghayati kesatuan hakiki dengan asal-usul Ilahi. Dalam kontek ini hubungan Tuhan dengan manusia digambarkan seperti dalang dengan wayang. Di samping itu, persatuan manusia dengan Tuhan juga diibaratkan seperti halnya tembaga emas. Apabila sebutan emas hilang, sebutan tembaga juga hilang. Dalam konteks ini hamba tetap hamba dan Tuhan tetap Tuhan. Dalam Suluk Residriyo disebut dengan istilah kawula maksih kawula, ingkang Gusti iya isih nama Gusti. Hal itu dapat dilihat pada Serat Ngabdul Jalil, pupuh 3, dhandhanggulo bait ke-27; dan pupuh 2, Sinom bait ke-2, 3, dan 4 di bawah ini sebagai berikut.

Yen sinepe Allah kang sayekti, maring jalmi kadi ki dhalang, kang sarta lan wayange, kang wayang wujudipun, lan malihe wujude kelir, iku anane ki dhalang, Nanging dhalang iku, wujude tan sabab wayang, He Juminah den becik sira satiti, pasemone punika.

Artinya:

Hubungan Allah dengan manusia, ibarat hubungan ki dalang dengan wayangnya dan wujud kelir, itu menandakan keberadaan ki dhalang. Namun, dalang itu keberadaannya bukan karena wayang. Hai Juminah, sebaiknya engkau waspada terhadap perumpamaan ini. 
........... Kanjeng Sunan muwus aris,ngilmu wahdat Tokid ing tegesnya Sanubari kang maca, kawula tunggal ing Gusti, Gusti tunggal kawula, apan kumpul dadi sawiji, Ing dalem kalimat takbir, munajat mring Yang Agung, Tan ana Gusti kawula, lebure papan lan tulis, pan umpama emas lawan dembagi. Wus ilang arane emas, ilang arane dembagi. Dene ingkang gumebyar, cahyane emas sayekti, Sira den iling lan titi, pasemone kang iku Pan Gusti dudu kawula, kawula pan dudu Gusti. Allah iku kumpule tan pangepokan.

\section{Artinya:}

......Kanjeng Sunan berkata lembut ilmu wahdah tauhid berarti, dengan keyakinan hati hamba itu bersatu dengan Tuhan. Tuhan bersatu dengan hamba, berkumpul menjadi satu di dalam kalimat takbir serta bermunajat kepada Yang Agung. Bersatunya Tuhan dan Hamba, bagaikan bersatunya papan tulis dan tulisan atau bersatunya emas dengan tembaga. Hilanglah sebutan emas, hilang pula sebutan tembaga. Adapun yang berkilauan itu adalah cahaya emas sejati. Engkau mesti ingat dan berhati-hati terhadap perumpamaan itu. Tuhan bukanlah hamba dan hamba bukanlah Tuhan, bersatu tanpa bersentuhan.

Persentuhan ajaran Islam sufistik dengan budaya Jawa sebagaimana disebutkan di atas telah teranyam, terpadu, dan terkubur dalam lipatan alam bawah sadar kolektif manusia serta terpatri menjadi cara berpikir masyarakat pendukungnya. Dengan kata lain, spiritualitas Islam Jawa yang tercermin dalam naskah sastra suluk Jawa pesisiran tidak sekadar menanamkan budaya, tetapi juga menanamkan sebuah paradigma berpikir. Lokalitas ini dalam perjalanan sejarah Nusantara setidaknya dapat menjadi katarsis kebudayaan dan dalam beberapa aspek mampu menjaga keharmonisan sosial, politik, dan kebudayaan. Bahkan ke depan warna lokal itu masih tetap aktual untuk menyempurnakan proses katalisasi dan pembangunan kebudayaan. 
Dalam perspektif keindonesiaan prospek sastra suluk Jawa pesisiran juga memiliki pengaruh yang penting dalam pemberian watak bangunan kebangsaan di Indonesia. Sikap akomodatif yang diapresiasikan oleh sastra suluk Jawa pesisiran misalnya, secara tidak langsung akan berdampak positif bagi penegakan nilai-nilai kemanusian. Lebih lanjut, sikap ini juga dapat memberikan sumbangan bagi upaya perekatan identitas bersama sebagai sebuah bangsa.

Dengan demikian sastra suluk Jawa pesisiran sebagai nilai-nilai budaya ketimuran yang luhur dapat dijadikan penyangga kebudayaan nasional dan dapat diharapkan dapat memberi ciri khas bagi jati diri bangsa Indonesia. Pemahaman terhadap nilai-nilai yang pernah hidup dalam masyarakat masa lampau dalam naskah lama merupakan modal utama bagi pembangunan nasional, baik dalam bidang politik, ekonomi, sosial, maupun budaya (Simuh 1999:3).

Selain itu, sastra suluk juga akan memberikan manfaat bagi masyarakat dalam rangka mempertahankan jati diri ketimuran. Mengingat pada saat ini peradaban global yang sudah tidak mengenal lagi batas-batas ruang atau waktu, tidak hanya menyajikan unsur-unsur positif bagi kemajuan umat, tetapi juga menawarkan filsafat materialisme dan skularisme yang sangat membahayakan bagi kehidupan ketimuran yang masih menjunjung nilai-nilai agama dan filsafat ketuhanan.

\section{Penutup}

Sastra suluk Jawa pesisiran merupakan hasil pergulatan atau interaksi antara Islam dan sastra Jawa. Karya sastra suluk pesisir produk pondok pesantren berkaitan dengan ajaran tasawuf. Corak spiritualitas Islam Jawa yang terkandung dalam literatur-literatur keagamaan Islam bertumpu pada aliran gkozalian yang bersifat ortodoks. Konsep 
spiritualitas itu berpuncak pada tataran makrifatullah yang dilakukan tanpa harus merasa bersatu dengan Tuhan, tetapi harus melakukan tahapan-tahapan yang diperbolehkan oleh syariat.

Penggalian kembali nilai-nilai tradisi spiritualitas dalam naskah sastra suluk Jawa pesisiran memiliki peran yang cukup penting dalam rangka atau upaya menegaskan kembali identitas budaya lokal. Penting, mengingat nilai-nilai tradisi spiritualitas merupakan budaya ketimuran yang luhur yang dapat dijadikan penyangga kebudayaan nasional dan sekaligus dapat memberi ciri khas bagi jati diri bangsa Indonesia. Selain itu, tradisi spiritualitas Islam Jawa juga ikut mewarnai dan menentukan pola pikir, cara, dan sikap pandang seseorang tentang nilai-nilai kemanusian dan kebangsaan yang plural.

\section{Daftar Pustaka}

Abdullah, M. Amin. (2000). Dinamika Islam Kultural: Pemetaan Atas Wacana Keislaman Kontemporer. Bandung: Mizan.

Al-Taftazani, Abu al- Wafa' al-Ghanimi. (1997). Sufi dari Zaman ke Zaman. Bandung: Penerbit Pustaka.

Azra, Azyumardi. (1994). Jaringan Ulama Timur Tengah dan Kepulauan Nusantara Abad XVII dan XVIII: Melacak Akar-akar Pembaruan Pemikiran Islam di Indonesia. Bandung: Mizan.

Baried, Siti Baroroh dkk. (1985). Pengantar Teori Filologi. Pusat Pembinaan dan Pengembangan Bahasa. Yogyakarta: Depdikbud.

Departemen Pendidikan Nasional. (2008). Kamus Besar Bahasa Indonesia. Jakarta: Balai Pustaka. 
Munawwir, Ahmad Warson. (1997). Kamus Al-Munawwir ArabIndonesia Terlengkap. Surabaya: Pustaka Progresif.

Murtadho, M. (2002). Islam Jawa: Keluar dari Kemelut Santri vs Abangan. Yogyakarta: Laperra.

Purnnama, Bambang dkk. (2002). Kesastraan Jawa Pesisiran: Sebagai Refleksi Sastra Nusantara di Jatim. Sidoarjo: Departen Pendidikan. Balai Bahasa Surabaya.

Sedyawati, Edi dkk. (2001). Sastra Jawa: Suatu Tinjauan Umum. Jakarta: Balai Pustaka.

Simuh. (1999). Sufisme Jawa: Transformasi Tasawuf Islam ke Mistik Jawa. Yogyakarta: Jaya Benteng Budaya.

Tohari, Ahmad dkk. (1998). Sastra dan Budaya Islam Nusantara: Dialektika Antarsisitem Nilai. Yogyakarta: SMF Adab IAIN Sunan Kalijaga.

W.M, Abdul Hadi dkk. (2003). Adab dan Adat: Refleksi Sastra Nusantara. Jakarta: Pusat Bahasa. Departemen Pendidikan Nasional.

Zulkifli. (2003). Sufi Jawa: Relasi Tasawuf-Pesantren. Yogyakarta: Pustaka Sufi. 